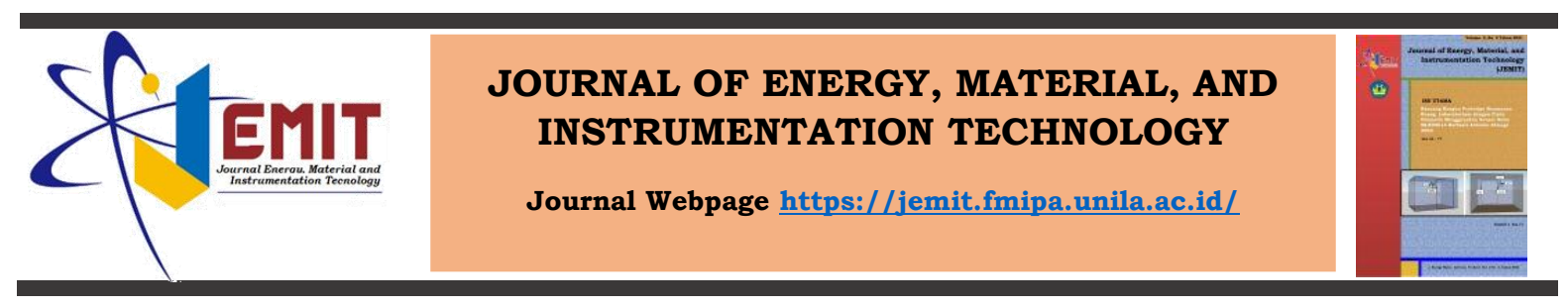

\title{
Rancang Bangun Prototipe Keamanan Ruang Laboratorium dengan Pintu Otomatis Menggunakan Sensor Suhu MLX90614 Berbasis Arduino Atmega 2560
}

\author{
Diana Margarini*, Sri Wahyu Suciyati, Arif Surtono, dan Gurum Ahmad Pauzi
}

Jurusan Fisika, Universitas Lampung, Bandar Lampung, Indonesia, 35141

\begin{tabular}{|c|c|}
\hline Article Information & Abstract \\
\hline $\begin{array}{l}\text { Article History: } \\
\text { Received October } 26^{\text {th }}, 2021 \\
\text { Received in revised from } \\
\text { October } 27^{\text {th }}, 2021 \\
\text { Accepted November } 18^{\text {th }} \text {, } \\
2021\end{array}$ & $\begin{array}{l}\text { Research on laboratory room security system has begun to be developed with } \\
\text { various kinds of inputs used. In this study, the design of a laboratory room } \\
\text { security prototype with automatic doors has been realized using the MLX90614 } \\
\text { temperature sensor based on Arduino Atmega } 2560 \text {. The design of this prototype } \\
\text { aims to design a prototype laboratoey room with automatic doors using a door } \\
\text { lock solenoid and a temperature sensor MLX90614. In addition, this system is } \\
\text { equipped with a counter to reduce and add people in the room using the FC-51 } \\
\text { infrared sensor. Data retrieval is done by detecting human temperature before } \\
\text { entering the room, when the temperature input is met, the door of the room will } \\
\text { open with a maximum limit of } 10 \text { people. The results showed that the system was } \\
\text { functioning properly, indicated by the state of the door that could open when it } \\
\text { received an input of temperature between } 35-37^{\circ} \mathrm{C} \text {, the door remained closed } \\
\text { when detecting of temperature other than } 35-37^{\circ} \text {, and the door remained closed } \\
\text { when the object in the room was up to } 10 \text { people. }\end{array}$ \\
\hline Informasi Artikel & Abstrak \\
\hline $\begin{array}{l}\text { Proses artikel: } \\
\text { Diterima } 26 \text { Oktober } 2021 \\
\text { Diterima dan direvisi dari } \\
27 \text { Oktober } 2021 \\
\text { Accepted } 18 \text { November } 2021\end{array}$ & $\begin{array}{l}\text { Penelitian tentang sistem keamanan ruang laboratorium mulai banyak } \\
\text { dikembangkan dengan berbagai macam input yang digunakan. Pada penelitian } \\
\text { ini telah direalisasikan rancang bangun prototipe keamanan ruang laboratorium } \\
\text { dengan pintu otomatis menggunakan sensor suhu MLX90614 berbasis Arduino } \\
\text { Atmega } 2560 \text {. Rancang bangun prototype ini bertujuan untuk merancang } \\
\text { prototipe ruang laboratorium dengan pintu otomatis menggunakan solenoid door } \\
\text { lock dan sensor suhu MLX90614. Selain itu, sistem ini dilengkapi dengan counter } \\
\text { sebagai pengurang dan penjumlah orang di dalam ruangan menggunakan sensor } \\
\text { infrared FC-51. Pengambilan data dilakukan dengan deteksi suhu manusia } \\
\text { sebelum memasuki ruangan, saat input suhu terpenuhi maka pintu ruangan } \\
\text { akan terbuka dengan batas maksimal ruangan sebanyak } 10 \text { orang. Hasil } \\
\text { penelitian menunjukkan sistem berfungsi dengan baik, ditunjukkan dengan } \\
\text { keadaan pintu yang dapat terbuka saat mendapat input suhu antara } 35-37^{\circ} \mathrm{C} \text {, } \\
\text { pintu tetap terutup saat mendeteksi suhu selain } 35-37^{\circ} \mathrm{C} \text {, dan pintu yang tetap } \\
\text { tertutup saat objek di dalam ruangan telah terdeteksi sebanyak } 10 \text { orang. }\end{array}$ \\
\hline
\end{tabular}

\section{Pendahuluan}

Pandemi covid-19 telah menyebar hampir di seluruh negara di dunia, termasuk Indonesia. Antisipasi pencegahan penularan virus corona dapat dilakukan dengan berbagai cara, salah satunya dengan pengecekan suhu tubuh. Tempat-tempat yang menerapkan pengecekan suhu tubuh yaitu, bandara, stasiun, kantor, mall, bahkan di sekolah dan kampus. Suhu tubuh manusia normal berkisar antara $36^{\circ} \mathrm{C}$ sampai $37.5^{\circ} \mathrm{C}$ (Isyanto $\&$ Irwan, 2017). Berdasarkan Peraturan Menteri Kesehatan Republik Indonesia nomor 382 ( 2020), salah satu pencegahan penularan covid-19 pada individu yaitu, dengan menjaga jarak minimal 1 meter, menghindari kerumunan, keramaian, dan berdesakan.

Dalam dunia pendidikan terdapat proses pembelajaran dengan teori dan praktik (Padmadewi \& Luh, 2018). Saat ini pembelajaran dengan teori dapat dilakukan tanpa tatap muka, sedangkan pembelajaran dengan praktik yang seharusnya dilakukan di laboratorium tidak dapat dilakukan karena kurangnya keamanan untuk mencegah penularan covid-19 (Setiyadi, 2020). Keadaan tersebut membuat pelaksanaan kegiatan praktikum tidak maksimal karena tidak didukung dengan peralatan yang dapat mencegah penularan covid-19 untuk mendukung kegiatan 
praktikum berlangsung seperti biasa. Oleh karena itu, diperlukan sistem keamanan pada ruangan laboratorium agar praktikan dapat melakukan kegiatan praktikum seperti biasa dengan menerapkan protokol kesehatan. Keamanan berupa pendeteksian suhu tubuh sebelum memasuki ruangan, pengendalian pintu otomatis, dan pembatasan kerumunan manusia di dalam ruangan.

Penelitian tentang sistem keamanan pintu telah dilakukan oleh Saputro \& Wibawanto (2016) dengan masukan berupa E-KTP berbasis RFID dan mikrokontroler Atmega 328 dan keluaran berupa solenoid door lock. Widcaksono \& Masyhadi (2018) membuat sistem keamanan pintu rumah dengan masukan SMS (Short Message Service) dan password menggunakan Arduino Uno dengan keluaran solenoid door lock, buzzer, dan LCD. Lonika \& Hariyanto (2019) membuat alat keamanan pintu apartemen dengan masukan QR code dengan Arduino Uno dan keluaran berupa solenoid door lock.

Sandar \& Saw (2019) membuat sistem kunci pintu dengan pengenalan wajah berbasis Raspberry Pi. Masukan pengenalan wajah menggunakan web camera dan keluaran berupa solenoid door lock. Penelitian model keamanan laboratorium dengan pintu otomatis telah dilakukan oleh Suwartika \& Sembada (2020) menggunakan masukan melalui keypad berbasis Arduino Uno dan keluaran menggunakan solenoid door lock, buzzer, dan LED. Sistem keamanan tersebut tidak dirancang untuk keamanan laboratorium di masa pandemi.

Penelitian tentang sistem keamanan ruang laboratorium ini menggunakan input berupa suhu tubuh manusia yang diukur menggunakan sensor suhu MLX90614. Keluaran suhu ditampilkan pada layar LCD 20×4. Ketika sensor MLX90614 mendeteksi suhu manusia antara $35-37^{\circ} \mathrm{C}$, maka solenoid door lock aktif dan motor servo bergerak untuk membuka pintu secara otomatis. Terdapat sensor infrared FC-51 berfungsi sebagai counter untuk menghitung jumlah orang di dalam ruangan.

\section{Metode Penelitian}

Alat dan bahan yang digunakan dalam penelitian ini yaitu, Arduino Atmega 2560, sensor suhu MLX90614, solenoid door lock $12 \mathrm{~V}$, relay, sensor infrared FC-51, motor servo SG90S, LCD 20×4 I2C, jumper, catu daya $12 \mathrm{~V}$, multimeter, akrilik, dan termometer digital infrared GF-Z99Y.

\subsection{Rancangan Keseluruhan Alat}

Rancangan alat pada penelitian sistem keamanan ruang laboratorium dengan pintu otomatis ini tersusun dalam suatu diagram blok rancangan alat yang dapat dilihat pada Gambar 1.

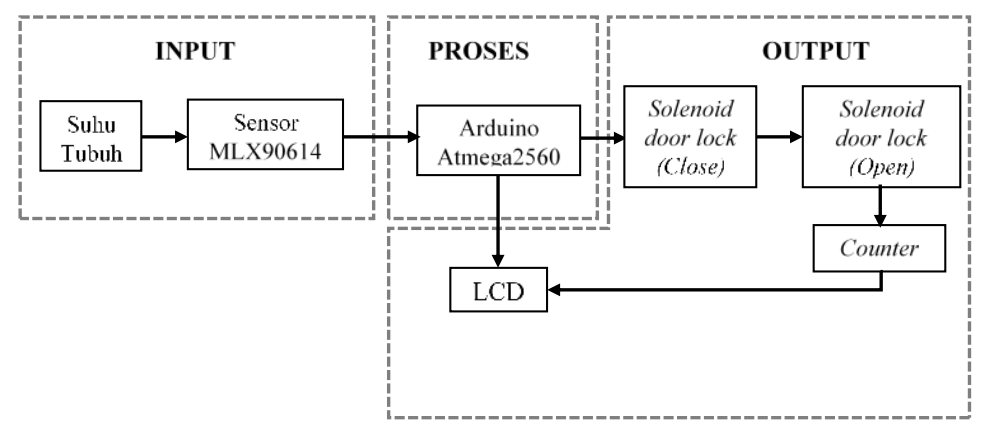

Gambar 1. Diagram blok cara kerja alat

Prinsip kerja prototipe keamanan ruang laboratorium dengan pintu otomatis didasarkan pada adanya objek (manusia) yang mendekati sensor MLX90614 pada jarak $1 \mathrm{~cm}$. Suhu tubuh yang terukur diterima oleh Arduino untuk dinyatakan sebagai nilai suhu yang ditampilkan pada LCD. Saat suhu tubuh yang terdeteksi antara $35^{\circ} \mathrm{C}-$ $37^{\circ} \mathrm{C}$, maka pintu ruangan akan terbuka secara otomatis. Kemudian terdapat dua buah sensor infrared FC- 51 yang masing-masing berfungsi sebagai penjumlah dan pengurang counter. Counter tersebut berguna untuk membatasi orang yang berada di ruangan. Jika sensor infrared FC-51 telah mendeteksi input sebanyak 10 orang maka relay yang terhubung dengan solenoid door lock tidak dapat terbuka. Delay yang digunakan agar pintu tertutup dan terkunci kembali setelah terbuka secara otomatis yaitu selama 3 detik. Rangkaian dari alat keamanan pintu ruang laboratorium dapat dilihat pada Gambar 2. 
Margarini D., Suciyati S.W., Surtono A., dan Pauzi G.A., Rancang Bangun Prototipe Keamanan Ruang

Laboratorium dengan Pintu Otomatis Menggunakan Sensor Suhu Mlx90614 Berbasis Arduino Atmega 2560,

Journal of Energy Material and Instrumentation Technology, Vol. 2, No. 4, 2021

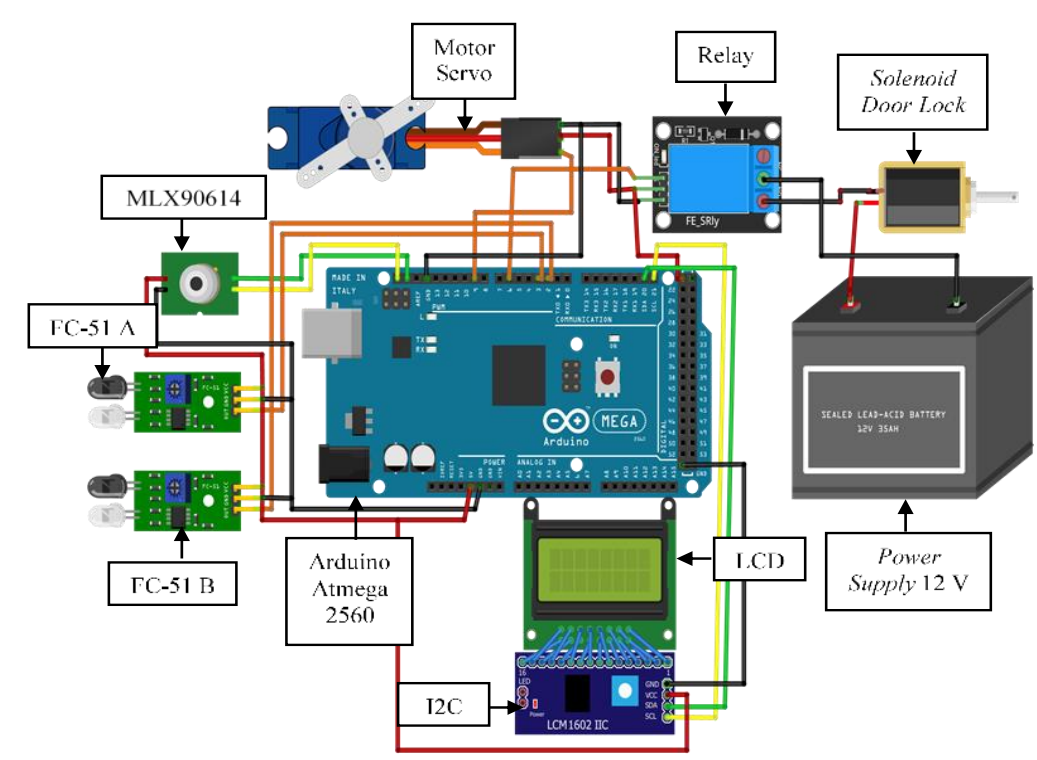

Gambar 2. Rangkaian alat keamanan laboratorium dengan pintu otomatis

Pada Gambar 2 dapat dijelaskan bahwa sensor MLX90614 memiliki 4 buah pin yang terhubung ke VCC, GND, SCL, dan SDA pada arduino. Selanjutnya, terdapat LCD 20×4 telah terhubung dengan I2C yang memiliki 4 buah pin dan dihubungkan dengan VCC, GND, SCL, dan SDA pada Arduino. Kemudian motor servo memiliki 3 buah pin yang terhubung dengan VCC, GND, dan D9 pada arduino. Solenoid door lock memiliki 2 buah pin yaitu VCC yang dihubungkan dengan VCC pada pin positif power supply dan GND yang dihubungkan dengan pin NO pada relay. Sedangkan relay memiliki 3 buah pin yang terhubung dengan VCC, GND, dan D6 pada arduino dan 3 buah pin untuk COM, NO, dan NC. Pin negatif power supply dihubungkan dengan pin COM pada relay. Selain itu, terdapat pula 2 buah sensor infrared FC-51 yang memiliki 3 buah pin terhubung dengan VCC, GND, D2 untuk FC-51 A, dan D3 untuk FC-51 B pada Arduino. Desain 3 dimensi dari prototipe keamanan pada pintu laboratorium dapat dilihat pada Gambar 3.

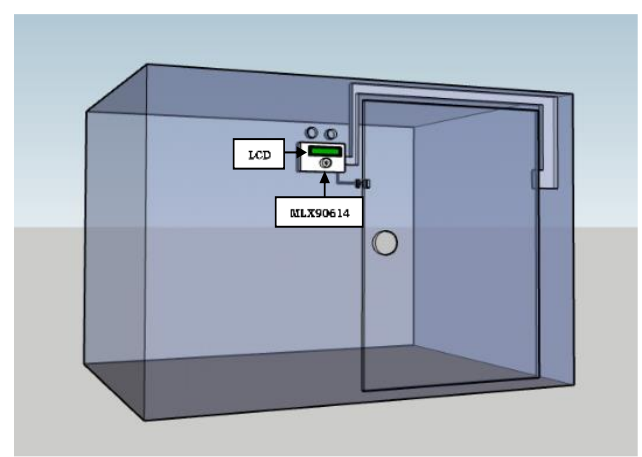

(a)

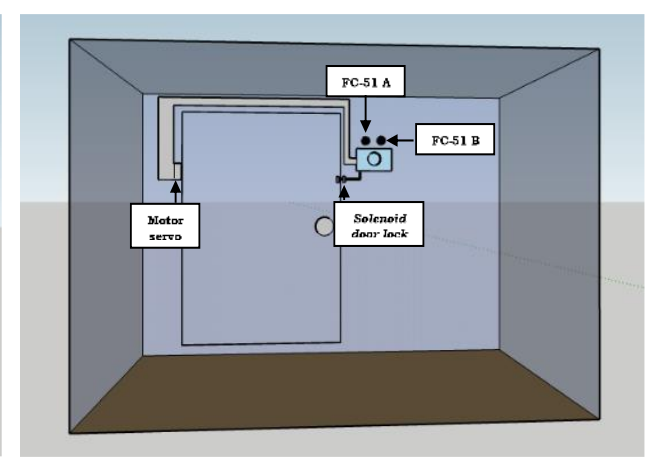

(b)

Gambar 3. Rancangan prototipe, (a) tampak depan, (b) tampak belakang

Rancangan pada Gambar 3, (a) merupakan tampilan depan dari prototipe laboratorium dengan pintu otomatis dengan ukuran sebesar $40 \times 40 \times 25 \mathrm{~cm}$. Pada gambar bagian depan terdapat sebuah kotak yang berisi LCD $20 \times 4$, Arduino Atmega 2560, relay, dan sensor MLX90614. Gambar 3, (b) memperlihatkan bagian dalam yang terdiri dari dua buah sensor yaitu, sensor infrared FC-51 A dan infrared FC-51 B untuk mengurangi dan menjumlah counter yang terhitung saat terdapat input. Alat tersebut dilengkapi solenoid door lock sebagai pengunci pintu dan motor servo sebagai penggerak pintu otomatis.

\section{Hasil dan Pembahasan}

\subsection{Realisasi Alat}

Prototipe ruang laboratorium dengan pintu otomatis menggunakan sensor suhu MLX90614 berbasis arduino atmega 2560 telah direalisasikan dengan hasil yang ditunjukkan pada Gambar 4. 


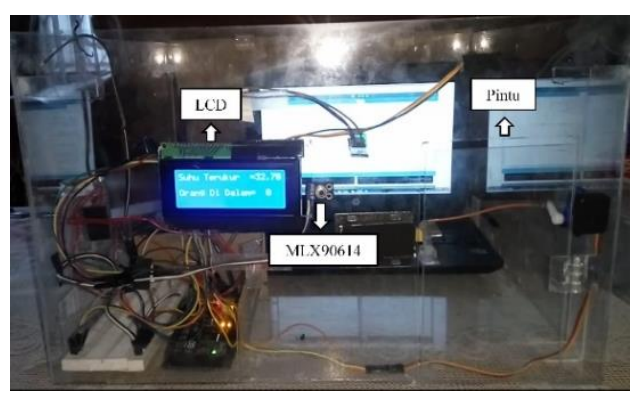

(a)

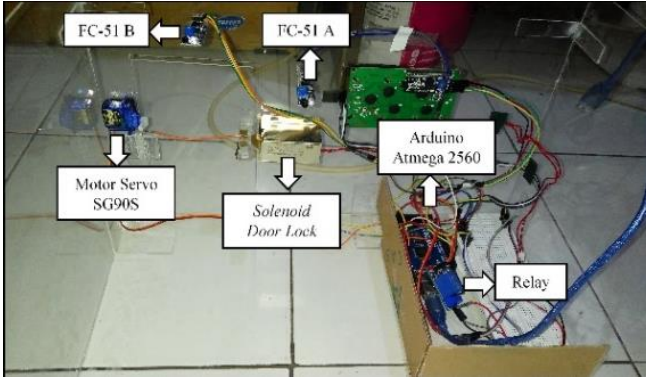

(b)

Gambar 4. Prototipe ruang laboratorium, (a) tampak depan, (b) tampak belakang

Pada Gambar 4, (a) terdapat LCD untuk menampilkan keluaran pendeteksian suhu dan jumlah orang yang berada di dalam ruangan, sensor MLX90614 sebagai input untuk mendeteksi suhu tubuh orang yang akan memasuki ruangan, dan terdapat pintu untuk jalur keluar dan masuk ruangan. Gambar 4, (b) terdapat beberapa komponen seperti, sensor infrared FC-51 A dan FC-51 B masing-masing untuk penambah dan pengurang counter. Motor servo SG90S untuk membuka dan menutup pintu secara otomatis. Solenoid door lock sebagai pengunci pintu otomatis. Arduino Atmega 2560 untuk pengatur program pada setiap komponen yang digunakan. Relay sebagai saklar untuk mengaktifkan solenoid door lock dengan sumber teganga sebesar $12 \mathrm{~V}$. Kotak yang digunakan untuk prototipe laboratorium menggunakan bahan akrilik dengan tebal $2 \mathrm{~mm}$ dan dimensi $40 \mathrm{~cm} \times 40 \mathrm{~cm} \times 25 \mathrm{~cm}$.

\subsection{Pengujian Sensor Infrared FC-51}

Sensor infrared FC-51 digunakan untuk mendeteksi jumlah orang yang berada di dalam ruangan laboratorium. Pengujian sensor infrared FC-51 dilakukan untuk mengetahui bahwa sensor dapat berfungsi dengan baik ketika digunakan untuk mendeteksi objek (orang) dengan membandingkan tegangan analog sensor dengan tegangan output sensor menggunakan multimeter. Persamaan 1 digunakan untuk menghitung nilai Vout berdasarkan data analog.

$$
V p=A D C \times \frac{\operatorname{Vin}}{1024}
$$

Nilai cacah ADC merupakan nilai yang dihasilkan sensor infrared FC-51 dengan output analog, Vin yaitu nilai input dari sensor infrared FC-51 (5V), sedangkan Nilai 1024 merupakan nilai maksimum dari keluaran analog sensor yang berasal dari ADC 10 bit pada Arduino (Asril \& Maria, 2018). Berdasarkan pengujian sensor infrared FC51 A yang telah dilakukan, diperoleh beberapa data pada Tabel 1 berikut.

Tabel 1. Data pengujian sensor infrared FC-51 A

\begin{tabular}{cccccc}
\hline $\begin{array}{c}\text { Jarak } \\
\text { (cm) }\end{array}$ & $\overline{\mathbf{V m}} \mathbf{( V )}$ & $\begin{array}{c}\text { Nilai Cacah } \\
\text { ADC }\end{array}$ & $\overline{\mathbf{V p}} \mathbf{( V )}$ & Kesalahan (\%) & Akurasi (\%) \\
\hline 1 & 0.130 & 28 & 0.135 & 3.92 & 96.08 \\
2 & 0.123 & 26 & 0.129 & 4.19 & 95.57 \\
3 & 0.130 & 27 & 0.134 & 2.77 & 97.23 \\
4 & 0.130 & 27 & 0.134 & 2.77 & 97.23 \\
5 & 0.130 & 28 & 0.135 & 3.92 & 96.08 \\
6 & 0.130 & 28 & 0.135 & 3.70 & 96.30 \\
7 & 0.130 & 28 & 0.135 & 3.92 & 96.08 \\
8 & 0.130 & 27 & 0.134 & 2.77 & 97.23 \\
9 & 0.130 & 28 & 0.135 & 3.92 & 98.48 \\
10 & 0.130 & 27 & 0.132 & 1.52 & 95.14 \\
11 & 0.137 & 29 & 0.144 & 4.86 & 97.86 \\
12 & 0.137 & 29 & 0.140 & 2.14 & 96.48 \\
13 & 0.137 & 29 & 0.142 & 3.52 & 96.48 \\
14 & 0.133 & 28 & 0.137 & 2.92 & 95.67 \\
15 & 0.137 & 29 & 0.142 & 3.52 & 97.85 \\
16 & 4.667 & 999 & 4.878 & 4.33 & 98.77 \\
17 & 4.790 & 1002 & 4.895 & 2.15 & 96.93 \\
18 & 4.737 & 982 & 4.796 & 1.23 & \\
19 & 4.730 & 999 & 4.880 & 3.07 & \\
20 & 4.717 & 991 & 4.837 & 2.48 & \\
\hline
\end{tabular}

Vm merupakan tegangan rata-rata sensor infrared FC-51 yang diukur menggunakan multimeter sebanyak 3 kali percobaan, sedangkan Vp tegangan rata-rata sensor infrared FC-51 dari hasil perhitungan nilai analog sensor sebanyak 3 kali percobaan. Sensor infrared FC-51 A dapat mendeteksi objek pada jarak $1-15 \mathrm{~cm}$ dengan nilai $(\mathrm{Vp})$ rata-rata $0.136 \mathrm{~V},(\mathrm{Vm})$ rata-rata $0.132 \mathrm{~V}$, kesalahan $2.94 \%$, dan akurasi $97.06 \%$. Sensor dapat mendeteksi dengan tegangan output mendekati $0 \mathrm{~V}$. Pada jarak $16-20 \mathrm{~cm}$ sensor sudah tidak dapat mendeteksi objek dengan 
Margarini D., Suciyati S.W., Surtono A., dan Pauzi G.A., Rancang Bangun Prototipe Keamanan Ruang

Laboratorium dengan Pintu Otomatis Menggunakan Sensor Suhu Mlx90614 Berbasis Arduino Atmega 2560,

Journal of Energy Material and Instrumentation Technology, Vol. 2, No. 4, 2021

menghasilkan (Vp) sebesar 4.857 V, (Vm) sebesar 4.728 V, kesalahan 2.65\% dan akurasi sebesar $97.35 \%$. Grafik pengujian tegangan output sensor infrared FC-51 A terhadap jarak ditunjukan pada Gambar 5.

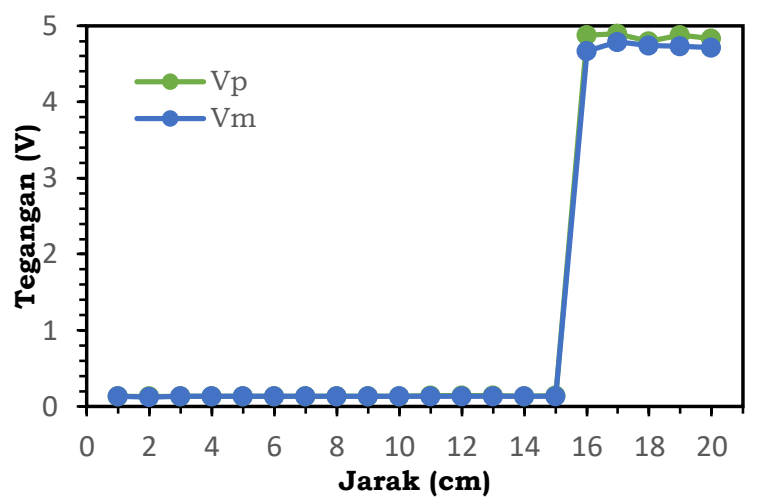

Gambar 5. Grafik pengujian Vout sensor infrared FC-51 A terhadap jarak

Keadaan sensor saat tidak mendeteksi objek ditunjukan dengan nilai tegangan output mendekati 5 V. Sensor infrared $\mathrm{FC}-51$ memiliki sudut deteksi sebesar $35^{\circ}$, sehingga semakin jauh jarak pendeteksian maka semakin luas area deteksinya (Robosoft, 2020). Penentuan jarak tersebut dapat diatur dengan memutar potensiometer yang terdapat pada modul sensor infrared FC-51. Perputaran searah jarum jam membuat jarak deteksi sensor semakin jauht. Hasil pengujian tegangan output sensor infrared FC-51 B terdapat pada Tabel 2.

Tabel 2. Data pengujian sensor infrared FC-51 B

\begin{tabular}{cccccc}
\hline Jarak (cm) & $\overline{\mathbf{V m}} \mathbf{( V )}$ & $\begin{array}{c}\text { Nilai } \\
\text { Analog }\end{array}$ & $\overline{\mathbf{V p}} \mathbf{( V )}$ & Kesalahan (\%) & Akurasi (\%) \\
\hline 1 & 0.130 & 27 & 0.134 & 2.77 & 97.23 \\
2 & 0.133 & 28 & 0.137 & 2.70 & 97.30 \\
3 & 0.133 & 28 & 0.139 & 3.89 & 96.11 \\
4 & 0.140 & 29 & 0.144 & 2.57 & 97.43 \\
5 & 0.140 & 30 & 0.145 & 3.65 & 96.35 \\
6 & 0.140 & 29 & 0.144 & 2.57 & 97.43 \\
7 & 0.140 & 29 & 0.144 & 2.57 & 97.43 \\
8 & 0.140 & 30 & 0.147 & 4.76 & 95.24 \\
9 & 0.140 & 29 & 0.142 & 1.41 & 98.59 \\
10 & 0.140 & 30 & 0.147 & 4.76 & 95.24 \\
11 & 0.140 & 30 & 0.145 & 3.45 & 96.55 \\
12 & 0.140 & 30 & 0.147 & 4.76 & 96.55 \\
13 & 0.140 & 30 & 0.145 & 3.45 & 95.24 \\
14 & 0.140 & 30 & 0.147 & 4.76 & 95.14 \\
15 & 0.137 & 29 & 0.144 & 4.86 & 98.49 \\
16 & 4.750 & 988 & 4.823 & 1.51 & 98.12 \\
17 & 4.707 & 991 & 4.841 & 2.77 & 95.16 \\
18 & 4.743 & 990 & 4.834 & 1.88 & 98.06 \\
19 & 4.640 & 999 & 4.876 & 4.84 & \\
20 & 4.797 & 1002 & 4.892 & 1.94 & \\
\hline
\end{tabular}

Saat objek berada pada jarak 16-30 cm, sensor infrared FC-51 B menghasilkan (Vp) sebesar $4.853 \mathrm{~V}$, (Vm) sebesar $4.727 \mathrm{~V}$, kesalahan $2.59 \%$ dan akurasi sebesar $97.41 \%$ dengan nilai tegangan output maksimum 5 V. Saat sensor ini mendeteksi objek pada jarak 1-15 cm diperoleh nilai (Vp) yaitu 0.143 V, (Vm) 0.137 V, kesalahan 4.20\%, dan akurasi $95.80 \%$ dengan tegangan output minimum sebesar 0 V. Grafik pengujian sensor infrared FC-51 B terhadap jarak dapat dilihat pada Gambar $\mathbf{6}$. 


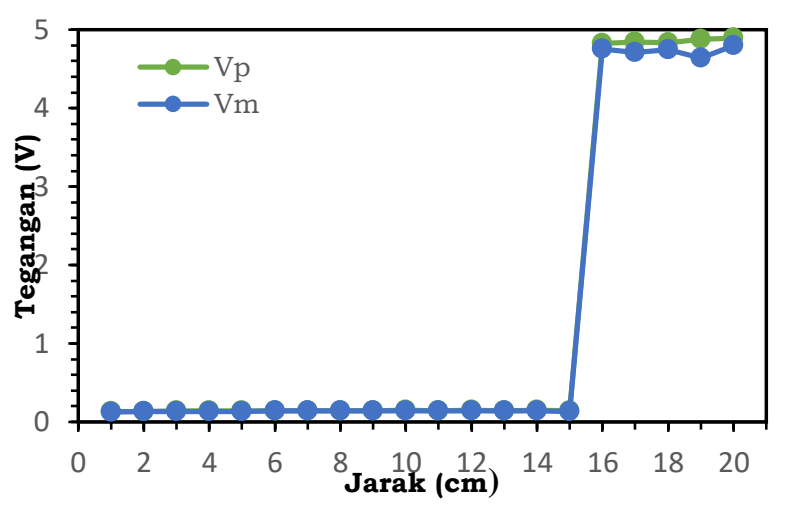

Gambar 6. Grafik pengujian Vout sensor infrared FC-51 B terhadap jarak

Menurut data hasil pengujian sensor infrared FC-51 dapat mendeteksi objek dengan baik pada jarak 1-15 cm karena pada hasil pengujian menunjukan bahwa nilai tegangan output sensor mendekati $0 \mathrm{~V}$ dan pada jarak 16-20 $\mathrm{cm}$ tegangan output mendekati $5 \mathrm{~V}$.

\subsection{Pengujian Sensor Suhu MLX90614}

Pengujian sensor ini bertujuan untuk mengetahui kelayakan sensor MLX90614 dapat bekerja dengan baik pada jarak tertentu. Data hasil pengujian sensor MLX90614 terhadap jarak dapat dilihat pada Tabel 3 berikut.

Tabel 3. Data pengujian sensor MLX90614

\begin{tabular}{ccccc}
\hline Jarak $(\mathbf{c m})$ & $\overline{\mathbf{T D}}\left({ }^{\circ} \mathbf{C}\right)$ & $\overline{\mathbf{S M}}\left({ }^{\circ} \mathbf{C}\right)$ & Kesalahan $\mathbf{( \% )}$ & Akurasi (\%) \\
\hline 1 & 36.17 & 35.86 & 0.86 & 99.14 \\
2 & 35.73 & 35.50 & 0.64 & 99.36 \\
3 & 35.53 & 35.17 & 1.01 & 98.99 \\
4 & 35.23 & 34.92 & 0.88 & 99.12 \\
5 & 35.06 & 34.78 & 0.80 & 99.20 \\
6 & 34.93 & 34.65 & 0.80 & 99.20 \\
7 & 34.77 & 34.49 & 0.81 & 99.19 \\
8 & 34.53 & 34.25 & 0.81 & 99.19 \\
9 & 34.43 & 34.12 & 0.90 & 99.10 \\
10 & 34.40 & 33.92 & 1.40 & 98.60 \\
\hline
\end{tabular}

Tabel 3 menunjukan data rata-rata pengujian sensor MLX90614 dengan alat ukur pembanding termometer digital infrared GF-Z99Y. Pengujian sensor MLX90614 dilakukan sebanyak 3 kali pengulangan dengan perubahan jarak mulai dari 1-10 cm. TD adalah nilai pengukuran suhu menggunakan termometer digital $\left({ }^{\circ} \mathrm{C}\right)$, sedangkan SM nilai pendeteksian suhu menggunakan sensor MLX90614 $\left({ }^{\circ} \mathrm{C}\right)$. Grafik pengujian sensor MLX90614 terhadap jarak dapat dilihat pada Gambar 7.

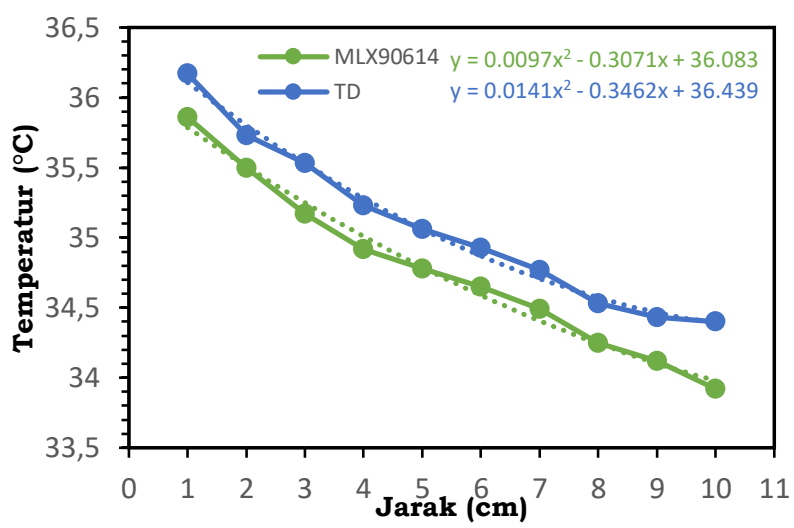

Gambar 7. Grafik hubungan sensor MLX90614 dan termometer digital terhadap jarak

Gambar 7 menunjukan pengukuran temperatur sensor MLX90614 dan termometer digital dipengaruhi oleh jarak. Semakin jauh jarak pengukuran, maka hasil pengukuran sensor MLX90614 dan termometer digital semakin kecil. Berdasarkan Gambar 7 dapat diperoleh hubungan antara sensor MLX90614 dan termometer digital yang dinyatakan dengan grafik regresi linier yang ditunjukan pada Gambar 8. 
Margarini D., Suciyati S.W., Surtono A., dan Pauzi G.A., Rancang Bangun Prototipe Keamanan Ruang

Laboratorium dengan Pintu Otomatis Menggunakan Sensor Suhu Mlx90614 Berbasis Arduino Atmega 2560,

Journal of Energy Material and Instrumentation Technology, Vol. 2, No. 4, 2021

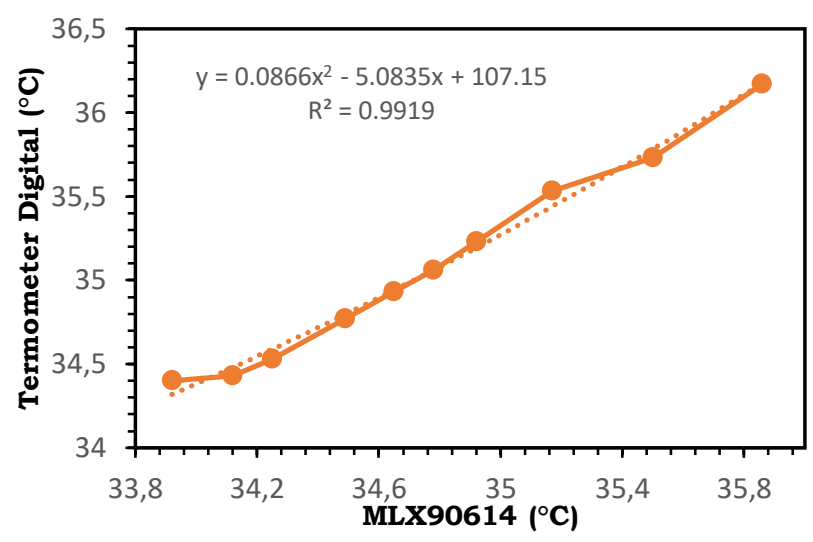

Gambar 8. Grafik kalibrasi sensor MLX90614 dan termometer digital

Grafik pada Gambar 8 digunakan untuk mendapatkan persamaan polinomial orde 2 yang ditunjukkan pada Persamaan 2.

$$
y=0.0866 x^{2}-5.0835 x+107.15
$$

Persamaan 2 adalah persamaan yang digunakan untuk mengkalibrasi sensor MLX90614 agar hasil pengukuran dapat mendekati nilai termometer digital. Kalibrasi sensor ini dilakukan dengan cara memasukkan persamaan tersebut ke dalam program pada software Arduino IDE.

\subsection{Pengambilan Data dan Analisis Sistem}

Pengambilan data dilakukan dengan menggunakan objek berupa manusia dengan suhu tubuh yang berbeda. Hasil pengujian prototipe ruang laboratorium saat objek memasuki ruangan ditunjukan pada Gambar 9.

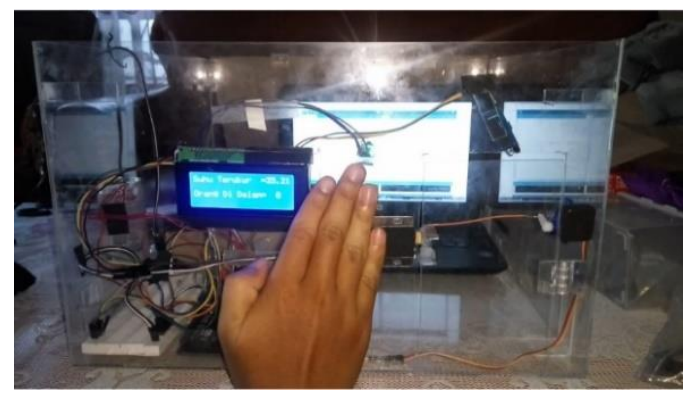

Gambar 9. Pengujian prototipe laboratorium saat objek masuk ruangan

Suhu objek dapat terdeteksi menggunakan sensor MLX90614 dan hasil pendeteksian terlihat pada LCD. Ketika suhu yang terdeteksi memenuhi antara $35-37{ }^{\circ} \mathrm{C}$, maka pintu secara otomatis akan terbuka. Pintu akan terbuka dalam waktu 3 detik, kemudian akan tertutup dan terkunci kembali. Penambahan counter untuk menghitung jumlah orang di dalam ruangan dapat dilihat pada Gambar 10.

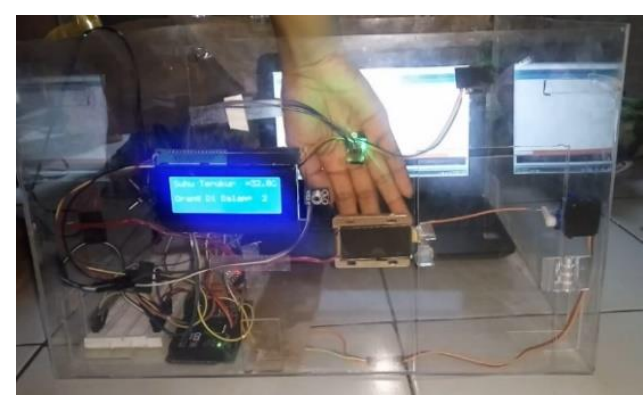

(a)

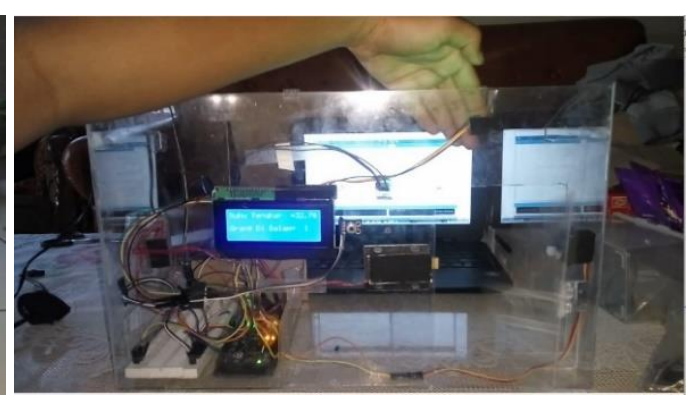

(b)

Gambar 10. (a) Penambahan counter, (b) pengurangan counter

Gambar 10, (a) saat objek memasuki ruangan terdapat sensor infrared FC-51 A yang akan mendeteksi objek dan akan menambah counter untuk menghitung jumlah orang yang berada di dalam ruangan. Gambar 10, (b) terlihat objek sedang mengurangi counter menggunakan sensor infrared FC-51 B dan terlihat pada layar LCD jumlah 
Margirini dkk, 2021/ J. Energy Mater. Instrum. Technol. Vol. 2 No. 4, 2021

orang di dalam ruangan berkurang dan pintu secara otomatis terbuka. Tabel 4 menunjukkan data hasil pengujian prototipe ruang laboratorium.

Tabel 4. Data pengujian prototipe laboratorium saat objek masuk ruangan

\begin{tabular}{cccc}
\hline No & Suhu $\left.\mathbf{(}^{\circ} \mathbf{C}\right)$ & Keadaan pintu & $\begin{array}{c}\text { Jumlah orang di dalam } \\
\text { ruangan }\end{array}$ \\
\hline 1 & & Terbuka & 1 \\
2 & 35.13 & Terbuka & 2 \\
3 & 35.75 & Terbuka & 3 \\
4 & 35.52 & Terbuka & 4 \\
5 & 35.69 & Terbuka & 5 \\
6 & 35.71 & Terbuka & 6 \\
7 & 36.18 & Terbuka & 7 \\
8 & 36.34 & Tertutup & 7 \\
9 & 37.26 & Terbuka & 8 \\
10 & 36.69 & Tertutup & 8 \\
11 & 38.08 & Tertutup & 8 \\
12 & 37.37 & Terbuka & 9 \\
13 & 36.89 & Terbuka & 10 \\
14 & 36.39 & Tertutup & 10 \\
15 & 37.52 & Tertutup & 10 \\
\hline
\end{tabular}

Pada Tabel 4 terlihat bahwa rancangan prototipe ruang laboratorium dapat bekerja untuk membuka pintu pada suhu antara $35-37^{\circ} \mathrm{C}$. Saat suhu lebih dari suhu yang ditetapkan, maka sistem tidak akan membuka pintu. Pada Tabel 4 terdapat suhu objek yang tidak dapat membuka pintu ruangan, seperti pada suhu $37.26^{\circ} \mathrm{C}$ jumlah orang di dalam ruangan tetap menunjukkan 7 orang, suhu $38.08^{\circ} \mathrm{C}$ dan $37.37^{\circ} \mathrm{C}$ tetap menunjukkan 8 orang, suhu $37.52^{\circ} \mathrm{C}$ tetap menunjukkan 10 orang di dalam ruangan. Kemudian, saat kapasitas ruangan sudah maksimal yaitu sebanyak 10 orang, maka pintu tidak akan terbuka walaupun suhu yang terdeteksi $35.15^{\circ} \mathrm{C}$ termasuk batas suhu yang ditentukan untuk membuka pintu ruangan. Tabel 5 menunjukkan data hasil pengujian prototipe ruang laboratorium secara keseluruhan.

Tabel 5. Data pengujian prototipe laboratorium secara keseluruhan

\begin{tabular}{cccc}
\hline No & Suhu & Keadaan pintu & $\begin{array}{c}\text { Jumlah orang di dalam } \\
\text { ruangan }\end{array}$ \\
\hline 1 & 36.01 & Terbuka & 1 \\
2 & 32.83 & Terbuka & 0 \\
3 & 35.23 & Terbuka & 1 \\
4 & 35.92 & Terbuka & 2 \\
5 & 35.62 & Terbuka & 3 \\
6 & 32.80 & Terbuka & 2 \\
7 & 36.30 & Terbuka & 4 \\
8 & 35.88 & Terbuka & 3 \\
9 & 32.72 & Terbuka & 4 \\
10 & 35.21 & Terbuka & 4 \\
11 & 37.26 & Tertutup & 4 \\
12 & 38.06 & Tertutup & 5 \\
13 & 35.69 & Terbuka & 5 \\
14 & 37.55 & Tertutup & 5 \\
15 & 36.37 & Terbuka & 6 \\
16 & 32.92 & Terbuka & 7 \\
17 & 35.13 & Terbuka & 6 \\
18 & 35.23 & Terbuka & 7 \\
19 & 33.07 & Terbuka & 5 \\
20 & 36.21 & Terbuka & \\
\hline
\end{tabular}

Pengujian dilakukan saat objek masuk ruangan dan saat objek keluar ruangan. Pengambilan data dilakukan secara acak untuk mengetahui bahwa sistem berfungsi dengan baik. Suhu kurang dari $35^{\circ} \mathrm{C}$ adalah suhu lingkungan tanpa dipengaruhi objek. Pada tabel di atas suhu kurang dari $35^{\circ} \mathrm{C}$ menunjukan bahwa counter pengurang sedang bekerja dari dalam ruangan. Suhu $35-37^{\circ} \mathrm{C}$ pada tabel di atas merupakan suhu manusia yang terdeteksi oleh sensor MLX90614, kemudian counter penambah bekerja dari dalam ruangan. Suhu lebih dari $37^{\circ} \mathrm{C}$ dari Tabel 5 merupakan suhu manusia yang melebihi batas suhu yang ditentukan, sehingga tidak dapat digunakan untuk membuka pintu ruangan dan counter penambah tidak akan menghitung jumlah orang yang masuk.

\section{Kesimpulan}

Rancangan prototipe ruang laboratorium dengan pintu otomatis berfungsi dengan baik, ditunjukkan dengan keadaan pintu dapat terbuka saat input suhu antara $35-37^{\circ} \mathrm{C}$, pintu tetap terutup saat mendeteksi suhu selain 35$37^{\circ} \mathrm{C}$, dan pintu tetap tertutup saat objek di dalam ruangan terdeteksi sebanyak 10 orang. Pengujian sensor infrared FC-51 menunjukan sensor dapat mendeteksi objek pada jarak 1-15 cm dengan kesalahan FC-51 A $2.94 \%$ dan akurasi 97.06 \%. Pengujian tegangan output FC-51 B diperoleh kesalahan $4.20 \%$ dan akurasi $95.80 \%$. Pada jarak 
Margarini D., Suciyati S.W., Surtono A., dan Pauzi G.A., Rancang Bangun Prototipe Keamanan Ruang

Laboratorium dengan Pintu Otomatis Menggunakan Sensor Suhu Mlx90614 Berbasis Arduino Atmega 2560,

Journal of Energy Material and Instrumentation Technology, Vol. 2, No. 4, 2021

16-20 cm sensor infrared FC-51 tidak dapat mendeteksi objek di depannya dengan kesalahan pengujian tegangan output FC-51 A $2.65 \%$ dan akurasi $97.35 \%$. Hasil pengujian tegangan output FC-51 B diperoleh kesalahan $2.59 \%$ dan akurasi $97.41 \%$. Kalibrasi sensor suhu MLX90614 menunjukkan bahwa semakin kecil jarak yang digunakan, maka hasil deteksi suhu semakin kecil, sehingga pendeteksian suhu lebih baik pada jarak $1 \mathrm{~cm}$.

\section{Daftar Pustaka}

382, P. M. K. R. I. (2020). Protokol Kesehatan bagi Masyarakat di Tempat dan Fasilitas Umum Dalam Rangka Pencegahan dan Pengendalian Corona Virus Disease 2019 (Covid-19). Jakarta: Menteri Kesehatan Republik Indonesia.

Asril, A. A., \& Maria, P. (2018). Prototipe Smart Parking Lift System Berbasis Arduino. Jurnal Poli Rekayasa, 13(2), 21-31.

Isyanto, H., \& Irwan, J. (2017). Monitoring Dua Parameter Data Medik Pasien (Suhu Tubuh dan Detak Jantung) Berbasis Arduino Nirkabel. Jurnal Elektum, 15(1), 19-24.

Lonika, T., \& Hariyanto, S. (2019). Simulasi Smart Door Loock Berbasis QR Code menggunakan Arduino Uno Pada Penyewaan Apartemen Online. Jurnal Algor, 1(1), 9-15.

Padmadewi, N. N., \& Luh, P. A. (2018). Literasi di Sekolah dari Teori ke Praktik. Bali: Nilacakra.

Robosoft. (2020). IR Sensor Based Obstacle Detection Sensor Module (Single). Retrieved from https://cdn.instructables.com/ORIG/FW9/SBS0/J3EPQTB8/ FW9SBS0J3EPQTB8

Sandar, S., \& Saw, A. (2019). Development of a Secured Door Lock System Based on Face Recognition using Raspbaerry Pi and GSM ModuleNo Title. International Journal of Trend in Scientific Research and Development, 3(5), 357-361.

Saputro, E., \& Wibawanto, H. (2016). Rancang Bangun Pengaman Pintu Otomatis Menggunakan E-KTP Berbasis Mikrokontroler Atmega 328No Title. Jurnal Teknik Elektro, 8, 1-4.

Setiyadi, S. (2020). Pembuatan Aplikasi Pembelajaran Praktikum PLC Secara Daring Menggunakan PLC Omron CP1E untuk Menghadapi Pandemi Covid-19. Jurnal Teknologi, 11(2), 71-76.

Suwartika, R., \& Sembada, G. (2020). Perancangan Sistem Keamanan Menggunakan Solenoid Door Lock Berbasis Arduino Uno pada Pintu Laboratorium di PT.XYZ. Jurnal Elektro Komputer Teknik, 4(1), 62-74.

Widcaksono, D., \& Masyhadi. (2018). Rancang Bangun Secured Door Automatic System untuk Keamanan Rumah Menggunakan SMS Berbasis ArduinoNo Title. Jurnal Kajian Teknik Elektro, 3(1), 52-66. 